\title{
Development of Madrasah Teacher Professionalism by Strengthening the Khalifah Concept and Islamic Psychosocial Perspective
}

\author{
Syahraini Tambak \\ Program Studi Pendidikan Agama Islam \\ Universitas Islam Riau \\ Pekanbaru, Indonesia \\ syahraini_tambak@fis.uir.ac.id
}

Amril M

Lembaga Penjaminan Mutu

Universitas Islam Negeri Sultan Syarif Kasim Riau Pekanbaru, Indonesia

amrilmansur@uin-suska.ac.id

\author{
Zuriatul Khairi \\ Fakultas Psikologi \\ Universitas Islam Negeri Sultan Syarif Kasim Riau \\ Pekanbaru, Indonesia \\ zuriatul.khairi@uin-suska.ac.id
}

Desi Sukenti

Fakultas Keguruan dan Ilmu Pendidikan

Universitas Islam Riau

Pekanbaru, Indonesia

desisukenti@edu.uir.ac.id

\begin{abstract}
The purpose of this study is to analyze the model of professionalism development of madrasah teachers by strengthening the khalifah concept and Islamic psychosocial in Madrasah Aliyah Riau Province. Putting the khalifah concept and Islamic psychosocial as a variable forecasters is one approach in developing the professionalism of madrasah teachers. A total of 397 teachers were used as research samples Madrasah Aliyah teachers in 12 districts/cities throughout Riau Province. Using a quantitative research design and an ex post facto research approach, a questionnaire was established to measure the $k$ halifah concept and Islamic psychosocial as well as tests to measure the professionalism of madrasah teachers. Data were analyzed using descriptive statistics for variable levels and inferential statistics to test hypotheses developed through t-test, ANNOVA, and linear regression. The results show that the level of khalifah concept and Islamic psychosocial teachers are at a high stage, while the professionalism of Madrasah Aliyah teachers is at a low stage. This study also concluded that the khalifah concept and Islamic psychosocial simultaneously affect the professionalism of Madrasah Aliyah teachers in Riau Province $(0.470)$ or $(47 \%)$. The findings of this study reconstruct the guidance of a prevention module as well as an intervention on the professionalism of madrasah teachers with the khalifah concept and Islamic psychosocial and applied to all Madrasah Aliyah teachers in Indonesia.
\end{abstract}

Keywords-khalifah concept; Islamic psychosocial; professionalism; madrasah

\section{INTRODUCTION}

Mohammad Kosim [1] explains that: teachers are very strategic in Islam, because they carry a scientific and prophetic mission to educate students to master the science and guide the cautious man to God. Thus, the policy on the model of Islamic professional teachers in Indonesia is crucial because it is necessary to build high quality teachers [2].
One of the efforts of the Indonesian government in improving the quality of teachers is a certification program with the issuance of Law of the Republic of Indonesia Number 14 Year 2005 on Teachers and Lecturers [3]. However, this certification policy, according to Imam Nasruddin, has little impact on the quality of teachers in Indonesia [4]. Ahmad Salim [5], in 2011 conducted a survey of 15 thousand teachers in Indonesia who have been certified in 2006 until the year 2008 found a decrease in the performance of certified teachers as much as 34\%. The data depicted in Kompas newspaper, proves based on the certified teacher's competency test result that the average value of teacher competence test is 44,55 based on data processing 243,619 from 373,515 people [6].

Similarly, in Madrasah Aliyah in Riau Province both public and private that the professionalism of some teachers is still low. While madrasah management has made policy for teachers to attend various training and other education activities to improve performance [7]. In addition, the certification program as mandated by the law that has been launched by the government by providing certification allowance for all teachers in Indonesia. With this, the true professionalism of Madrasah Aliyah teachers has improved performance, creativity, and innovation in teaching students. Professionalism is linked to the high skills that master the various sciences, methods, evaluation to the development of communication and information technology media and integrate it with Islamic education. According to Wekke and Lubis [8], the professionalism of teachers is related to producing quality learning, quality evaluation, and learning quality management so that learners can understand the learning materials quickly.

Thus, the professionalism of madrasah teachers is required to be developed in order to produce quality learners and the progress of Indonesian madrasah institutions. For the development of professionalism of madrasah teachers is 
assumed to be done by giving the concept of khalifah and psychosocial Islam in madrasah teachers. According to Neviyarni [9] teachers who understand the concept of the caliphs give a positive impact for the improvement of teachers tasks in realizing learners have the ability and activities that draws him to Allah SWT. Psychosocial Islam according to Khairil Anwar gives high contribution for the development of human quality in every profession that is run [10].

The formulation of the problems presented in this research is; What is the level of concept of khalifah, psychosocial Islam, and professionalism of Madrasah Aliyah teachers in Riau Province?; How is the concept of khalifah, Islamic psychosocial, and professionalism based on the background of Madrasah Aliyah teachers in Riau Province?; How is the influence of khalifah concept and Islamic psychosocial in developing the professionalism of Madrasah Aliyah teachers in Riau Province? Based on this, this research aims to build a model of professionalism development of Madrasah Aliyah teachers in Riau Province by strengthening the concept of khalifah and psychosocial Islam.

Research on teacher professionalism has been done by researchers in education, management, human resources, and others. Research conducted by Jenny Jonston [11], about Issues of professionalism and teachers: critical observations from research and the literature illustrates that the professionalism of teachers is very important for educational institutions to give birth to quality learners. This study criticizes teachers who do not attach importance to quality in the learning process because of the professionalism of teachers associated with the development of a nation's generation and influential for the progress of the nation itself.

Nurlaila's [12] research on the professionalism of teachers in improving the quality of education with a qualitative approach. Produce that a teacher must be able to become professional educator that they are able to educate learners with heart, able to pass exploration, able to develop talent owned by learners, develop learners, guide learners life, and able to bring learners know Allah SWT as its creator. Another researcher Muhammad Riza Zainuddin [13], on the management of madrasah heads in developing the professionalism of teachers of Islamic Religious Education, with a qualitative research brief of case studies. This research confirms that the head of madrasah is required to hold various planning (planning) so that the development of professionalism of teachers will be the habit of each subordinate and teacher respectively.

Another researcher conducted by Nyanyu Khodijah [14] on reflective learning as an alternative approach in improving the quality of learning and professionalism of teachers of Islamic Education, with a qualitative approach to case studies. This research resulted that reflective learning is one alternative approach that can be used by teachers of Islamic Education to improve the quality of learning and professionalism. Research conducted by Bambang Budi Wiyono, Kusmintardjo, \& Ahmad Supriyanto [15], about the grand design of teacher professional development model based on teacher performance determinant. The study used a development research design, in 90 teachers and 28 principals with quota random sampling. The results showed that effective teacher coaching model is done through five stages, namely requirement analysis, preparation of coaching program, implementation of coaching program, evaluation of coaching program, and follow up of coaching result.

Subanji and Isnandar [16] research that examined teacher professionalism improvement through Teacher quality improvement program (TEQIP) based on lesson study using experimental approach to 1080 respondents in five Provinces East Kalimantan 180 teachers, East Java 360 teachers, West Nusa Tenggara 180 teachers, Bengkulu 180 , and Jambi 180 teachers. The professionalism developed in teachers in TEQIP activities includes: (1) academic competence; (2) pedagogic competence; and (3) productivity performance. This study confirms that teacher professionalism can be improved through lesson study-based teacher quality improvement programs (TEQIP). Research conducted by Muhammad Nasir [17], on the professionalism of teachers of Islamic Religious Education (an effort to improve quality through LPTK), with library research approach. This study resulted in the ideal and professional teachers expected; a) teachers who have four main competencies: pedagogic, professional, social, and personality competence, b) teachers who have certain skills in accordance with the subject area being taught and c) teachers who are not only professional and ideal in various teaching methods but also experts and professional in various educational methods.

\section{LITERATURE REVIEW}

\section{A. Khalifah Concept}

To construct the conceptual framework of this study, several supporting theories are needed to explain the relationships between the variables. Another thing to see the role of each variable with the problems that want to know from this research is the problem of professionalism of madrasah teachers. Based on the term of khalifah in this Qur'an, popping theory that connects with the role of human as teacher on earth. Tracing the concept of the caliph can be seen from the three theories proposed by Raghib al-Isfahani, M. Hamdani Bakran AdzDzaky and Amril M. Raghib al-Isfahani [18] said there are three human ideal functions on earth, namely as khalifah, 'abdullah, and imarat al-ard. Humans as a khalifah are following in the footsteps of Allah SWT according to human ability in divine deeds, or follow / imitate Allah SWT in behaving by implementing makarim al-syari'a. By seeking makarim alsyari'a, man deserves the khalifah of Allah SWT. To arrive at this position, one must first perform the purification of the soul just as a person first purifies the body before performing the worship. Makarim al-syari'a with its contents like wisdom, establishes justice among men, ihsan (good-natured) and fadl (virtuous), besides interpreted by Raghib al-Isfahani as a way to go to jannat al-ma'wa, as well as human activities as the khalifah of Allah SWT.

M. Hamdani Bakran Adz-Dzaky [19], stated that a khalifah he must have the potential to prosper the earth. Man in the presence of Allah SWT is an extraordinary creature because it falls His choice to man to be a khalifah as a substitute of Allah SWT in managing the divine nature and ecosystem the rahmatan li al-'alamin. Therefore as a caliph, man is endowed by Allah with Divine potentials together with the presence of "nur" and "spirit" that is fitri in man, namely the potential of 
divine nur, the potential of the divine soul, the potential of the divine $n a f s$, the potential of the divine qalb, and divine sensory potential.

Meanwhile, according to Amril M [20], human as a khalifah is the representative of Allah on earth which is equipped with the potential of sense, senses and heart and has an actual morality by running makarim al-syari'ah. Hence man has three powers i.e. mufakkara (thinking) produces the ability to distinguish between the difference between the jamil (beautiful) and qabih (ugly) in action; the power of shahwiya (lust) with 'iffa (modest), then this power will be guided by judgment (generosity) and generosity; power hamiyya (angry surge) through mengekangnya, resulting in hilm (polite) which in turn can also produce syaja'ah (bold). Similarly with these three powers, the soul will produce 'is (just) and ihsan (goodminded). The forms of makarim al-syari'a as a result of the purification of the soul not only can be called the human identity as khalifah of Allah SWT, but also in principle is the realization of malakiah elements that have been implanted in man as his spiritual strength, such as wisdom), is jud (generous), syaja'ah (bold), iffa (modest) as well as the properties that make it.

\section{B. Islamic Psyichosocial}

Psychosocial tracing of Islam, can be seen from two important theories of the theory proposed by Erikson and Khairil Anwar. Erikson's psychosocial theory of human development further leads to the development of identity. Erikson asserted that human development applies continuously throughout his life. Erikson [21] states in his psychosocial development theory that each individual through eight developmental rankings is named as psychosocial rank. Each ranking is illustrated by various psychological crises that the individual needs to solve before the individual will experience trouble to deal with the crisis in the future.

Khairil Anwar was the first psychologist to propose a theory of Islamic psychosocial that based his theories on the teachings of Islam. Psychosocial Islam according to Khairil Anwar [22] is putting views by involving perceptions, motivations, beliefs and social interactions that based on Islam to see a social problem that will affect the attributes of individual behavior in society. Human behavior must fulfill three things, namely: First, the intrinsic of Islam is to know the concept of caliph, recognize the concept of superiority, know the mission, build mission, create insight, commitment, identity, intelligence, ideals, creativity, obsession and worship. Secondly, social attitudes and standpoints are prejudice, mutual trust, mutual support, cooperation, openness, defensive, closed, restrained information (consisting of non-cooperative and downward appearance), life principle (consisting of material capital and spiritual capital) consisting of both positive and negative), interests (consisting of long-range and long-term), wisdom based on the rules of Allah and His Apostles, comparisons (high value standards, low value standards, objective and subjective), and literature (consisting of religion, philosophy and science). Third; $d a^{\prime} w a h$ and self-worth that is faith and sure which is true, istikhlas, ihsan (tawajuh), ihtisab, ikhlas (ridha), mujahadah nafsi, sure in al-kalimat al-thayyibah, good prayer, 'ilmu ma'a zikir, ikromul muslimin, and da'wah wa al-tabligh.

\section{Professionalism of Teacher}

Meanwhile, the professionalism of teachers is an openended situation of freedom for teachers to develop effective learning in higher standards with a sense of responsibility, and self-directed to continually develop themselves as teachers [23]. The success of teachers in implementing education and learning cannot be separated from the competence it has. No matter how high the spirit and motivation that the teacher has, the teacher's performance cannot be maximized if not mastered with the required professional competence control. Professional competence includes sub competence as follows: (1). mastering the scientific substance associated with the field of study, mastering the concepts of science in everyday life, and (2). master the steps of research and critical study to add insight and deepen the knowledge / subject matter of study [24].

The general theory of professionalism of madrasah teachers refers to the competence of Indonesian professional teachers, namely the Law of the Republic of Indonesia No 14 Year 2005 on Teachers and Lecturers, as well as the Regulation of the Minister of National Education Number 16 Year 2007, Government Regulation Number 74 Year 2008 and Regulation of the Minister of Religious Affairs of the Republic of Indonesia Number 16 of 2010 Article 16 [25]. Competence is a set of knowledge, skills, and behaviors that must be possessed, lived and mastered by teachers or lecturers in performing professional duties". Teacher competence as referred to in paragraph (1) of Government Regulation Number 74 Year 2008 covers pedagogic competence, personality competence, social competence, and professional competence obtained through professional education. [26].

Especially for madrasah teachers, based on regulation of the Minister of Religious Affairs of the Republic of Indonesia Number 16 Year 2010 Article 16 plus one more competence that is leadership competence [27]. Then there is the difference of competence of madrasah teachers with other teachers by adding one competence that is leadership competence. Thus, it can be emphasized here that the professionalism of madrasah teachers should refer to Regulation of the Minister of Religious Affairs No. 16 of 2010 with five competencies namely pedagogic competence, personality competence, social competence, professional competence, and leadership competence.

\section{METHODOLOGY}

This type of research is quantitative by using ex post pacto rule approach to explore the understanding and feelings of Madrasah Aliyah teachers about the concept of caliph and psychosocial in shaping professionalism [28]. The population of this study is all teachers who teach in Madrasah Aliyah both public and private in all districts/cities in Riau Province who teach subjects Aqidah Akhlak, Al-Qur'an Hadits, Fiqh, and History of Islamic Culture that has been certified or not certified. The population of this study amounted to 1088 consisting of 245 civil servant teachers and 980 private teachers in 315 madrasah's consisting of 18 State Madrasah Aliyah and 297 Private Madrasah Aliyah. By using the Slovin formula as a sampling technique with a tolerable percentage of error of $4 \%$ (0.04), the sample of this study is 397 teachers. To determine the sample in this study used systematic random sampling 
technique. This technique is a very useful sampling for a very large population. This sampling is a method where only the first element of the sample is randomly selected, while the next elements are systematically selected with a certain pattern.

Data collection was done by using questionnaire. Questionnaire is considered one of the best ways to get information from respondents. According Sugiyono [29] questionnaire is a technique of data collection conducted by giving a set of questions / statement written to the respondent to answer. The type of statement in the questionnaire can be open or closed with positive or negative sentences. Questionnaire is the easiest way to get information.

Furthermore, prepared the development of research instruments. To realize a measurement and in order to arrange the instrument of the concept of caliphate, it takes 11 (eleven) constructs namely; resourcefulness; sense; heart; wisdom; syaja'ah; 'iffah; syakha; hilm; jud; and mahabbah. Islamic psychosocial instruments are built on 10 (ten) constructs namely; the concept of the caliph; Islamic mission; Islamic prejudices; principles of Islamic life; the concept of Islamic experience; the concept of Islamic interest; concept of Islamic vision; Islamic comparison concepts; the concept of Islamic literature; and the concept of $d a^{\prime} w a h$ and self-worth. Instrument of teacher professionalism is built on 5 (five) constructs namely; pedagogic competence, social competence, professional competence, personality competence, social competence, and leadership competence.

Data were analyzed using descriptive and inference statistics. Descriptive statistics are used to refer to variables related to the presence of min (average) and percent. Statistical analysis of inference was used to test the hypotheses that have been developed through the $t$ test, ANOVA, and linear regression $\mathrm{p}<0.05$. Data were analyzed using SPSS version 20 software aid.

\section{RESULT}

\section{A. Characteristics of Madrasah Teachers}

The number of respondents surveyed is 397 , but the return questionnaire is 320 Madrasah Aliyah (public/private) teachers scattered in all regencies or cities in Riau Province, Indonesia. The teacher studied focused on the teacher of Aqidah Akhlak, the Qur'an Hadits, the Fiqh, and the History of Islamic Culture, both certified and uncertified. Table I shows the distribution of respondents in which 179 men or $56 \%$ of women and female respondents totaled 141 people or $44 \%$. While the age of respondents dominates the highest is between 31-40 years amounted to 143 people or $44 \%$. Age between 41-50 years amounted to 115 people or $35 \%$, age of respondents as many as 47 people or $16 \%$ less than 30 years. Teachers of Madrasah Aliyah are at least over 50 years old found 15 people or $5 \%$ of all respondents.

In table I it is also illustrated that the teachers of Madrasah Aliyah studied, $42 \%$ or 134 people have been certified i.e.> 5 years. The respondents who are less than 5 years old have been certified amounted to 109 people or 34\%. There are also Madrasah Aliyah teachers who have not been certified, as many as 77 people from 320 respondents or by $24 \%$. The respondent data in table 1 below also illustrates that $45 \%$ or 143 people from 320 Madrasah Aliyah teachers have taught between 10 to 20 years. The next 97 people or $30 \%$ of their teaching time is less than 10 years old. As many as 75 people or $23 \%$ have taught between 21 and 30 years. In fact there are teachers Madrasah Aliyah has long teaching that is above 30 years i.e. only 5 people from 320 respondents or by $2 \%$.

TABle I. SeX, Age, Older CertificAtion ANd Teaching Length

\begin{tabular}{|c|c|c|}
\hline Demographics & $\begin{array}{c}\text { Amount } \\
(\boldsymbol{N})\end{array}$ & $\begin{array}{c}\text { Percent } \\
(\%)\end{array}$ \\
\hline Gender & 179 & 56 \\
Man & 141 & 44 \\
Women & 47 & \\
Age & 143 & 16 \\
31-40 Year & 115 & 44 \\
41-50 Year & 15 & 35 \\
> 51 Year & 109 & 5 \\
< 5 Year & 134 & 34 \\
> 5 Year & 77 & 42 \\
Not certified yet & & 24 \\
\hline Old Certification & 30 \\
< 10 Year & 97 & 45 \\
10-20 Year & 143 & 23 \\
21-30 Year & 75 & 2 \\
\hline 30 Year & 5 & \\
\hline
\end{tabular}

\section{B. Khalifah Concepts of Madrasah Teachers}

The stage of khalifah concept which is at low level (score 49-147) is 104 respondents $(33 \%)$ and high stage (score 148$245)$ that is 216 people $(67 \%)$. In general, the average level of the concept of the respondent's caliph (Madrasah Aliyah teacher in Riau Province) (mean $=194.52, \mathrm{sd}=22.924)$ is at a high level. Based on this it is clearly illustrated that the concept of khalifah of Madrasah Aliyah teachers in Riau Province is at a high level stage.

Viewed from the gender, the concept of khalifah of Madrasah Aliyah teachers in Riau Province has differences. Using t-test, there is a different concept of Madrasah Aliyah teachers' caliph between male and female respondents, where the probability value $(0.001)$ is smaller than the significance value (0.05). These results indicate that the concept of female caliph teachers is higher than that of men in Madrasah Aliyah in Riau Province.

Judging from the age aspect of the teacher, using the ANOVA test, illustrates that there is no difference in the concept of khalifah based on the age of respondents, where the value of $F(1090.060)=2.096$, probability value $(0.101)$ is greater than significance $(0.05)$. These results illustrate that the age of respondents under 30 years, 31-40 years, 41-50 years, and above 50 years, is to have an understanding of the concept of the same caliph.

Judging from the background of the certification, using the ANOVA exam indicates that there is a different concept of the caliphate held by the teacher. Older certification teachers less than 5 years $($ mean $=196.72)$ are higher than teachers who have been certified 5 years (mean $=198.71$ and who have not certified $($ mean $=184.12)$, with probability value $(0.000)$ less than significance value $(0.05)$. 
Based on the length of teaching, using the ANOVA test, illustrates that there are differences in the concept of khalifah owned by Madrasah Aliyah teachers in Riau Province, with probability value $(0.000)$ smaller than the significance value (0.05). These results indicate that the concept of the caliph of the old group taught between 10 to 20 years is higher than that of the group that has taught between 21 and 30 years. Other data indicate that the group that has taught between 21 to 30 years is higher in the concept of khalifah compared with the group of respondents whose teaching length is less than 10 years. Groups that have taught less than 10 years of higher conception of caliphate compared with respondents who have taught 31 years and over.

\section{Islamic Psychosocial of Madrasah Aliyah Teachers}

The stages of Islamic psychosocial Madrasah Aliyah teachers in Riau Province are at low level (score 129-387), that is 112 people (35\%) and high level (score 388-645) as many as 208 people $(65 \%)$. In general, the average psychosocial level of Islamic teachers of Madrasah Aliyah in Riau Province (mean = $459.35, \mathrm{sd}=43.295$ ) is at a high score level. This illustrates that respondents generally have Islamic psychosocial in themselves and respondents generally have the concept of khalifah at a high stage $(65 \%)$.

Judging from the sex of the teacher, using the test shows that there are Islamic psychosocial differences between Madrasah Aliyah teachers between male respondents $($ mean $=$ 455.08) and female $($ mean $=464.77)$, where the probability value $(0.047)$ is smaller than the significance value $(0.05)$. These results indicate that the female psychosocial Islam female teacher is higher when compared with men in Madrasah Aliyah in Riau Province.

Based on the age of teachers, using the ANOVA test, there is no Islamic psychosocial difference, where the value $\mathrm{F}=$ 0.622 , probability value $(0.601)$ is greater than the significance value $(0.05)$. These results illustrate that the age of teachers of all levels below 30 years, ages 31-40 years, age 41-50 years, and age above 50 years is to have the same Islamic psychosocial.

Seen from the old certification, using the ANOVA exam, confirmed that there are Islamic psychosocial differences owned by Madrasah Aliyah teachers. Older madrasah certification teachers are less than 5 years old $($ mean $=459.89)$ higher than 5 years $($ mean $=464.59)$, and uncertified $($ mean $=$ 448.84), where the value $F=3.448$, with probability value (0.033) more small of significance value $(0.05)$.

Based on the length of teaching, using the ANOVA exam illustrates that there are Islamic psychosocial differences owned by Madrasah Aliyah teachers in Riau Province. This is indicated by the value $\mathrm{F}=9.627$ and the probability value $(0.000)$ is smaller than the significance value $(0.05)$. These results indicate that the old Islamic psychosocial teacher taught between 21 and 30 years (mean $=480.28)$ was higher than those who had taught between 10 to 20 years $($ mean $=457.39)$. Teachers who have taught between 10 and 20 years are higher in Islamic psychosocial than those who have taught less than 10 years $($ mean $=447.13)$. Groups who have taught less than 10 years of higher psychosocial Islam than teachers who have taught over 31 years $($ mean $=438.40)$.

\section{Professionalism of Madrasah Aliyah Teachers}

Professionalism of low-level madrasah teachers (score 129387 ) is 165 people (52\%) and high level (score 388-645) as many as 155 people (48\%). In general, the average level of professionalism of Madrasah Aliyah teachers in Riau Province $($ mean $=215.71, \mathrm{sd}=24.322)$ is at a low level.

Judging from the background of madrasah teachers, using the $\mathrm{t}$ test, there is no difference in the professionalism of Madrasah Aliyah teachers among male respondents as much as 179 respondents and 141 women respondents $(p=0.266>0.05)$. These results indicate that the professionalism of female teachers has no difference when compared to men in Madrasah Aliyah in Riau Province.

From the background of the respondent's age, it is envisaged that under the age of 30 years there are 47 people, 31-40 years (143 people), $41-50$ years (115 people), and above the age of 50 years (15 people). Using ANOVA exams, there was a difference in teacher professionalism based on teacher age in which the score $(p=0.012<0.05)$. These results indicate that the professionalism of group teachers aged between $41-50$ years is higher than that of teachers over the age of 50. Teacher groups over the age of 50 are higher in professionalism compared to teachers under the age of 30 . Teachers under the age of 30 are more professional than teachers aged 31-40.

From the certification background, it can be seen that the old teacher certification is less than 5 years as many as 109 people, more than 5 years as many as 134 people, and who have not certified as many as 77 people. Using the ANOVA exam resulted in a difference in the professionalism of Madrasah Aliyah teachers based on the length of certification $(\mathrm{p}=0.000$ $<0.05)$. These results indicate that the professionalism of Madrasah Aliyah teachers in certified groups is more than 5 (five) years higher than the certified group of less than 5 (five) years. Teachers groups that are less than 5 (five) years old are higher in professionalism than those who have not been certified.

From the old background teaching of Madrasah Aliyah teacher less than 10 years as many as 97 people (mean = 206.46), teaching time between 10-20 years as many as 143 people $($ mean $=4213.24)$, teaching duration between 21-30 years as many as 75 people $($ mean $=233.20)$, and teaching duration more than 31 years as many as 5 people $($ mean $=$ 203.60). Using ANOVA test resulted in differences of professionalism of Madrasah Aliyah teachers in Riau Province based on teaching duration $(\mathrm{p}=0.000<0.05)$. These results indicate that the professionalism of the old group teacher taught between 21 and 30 years is higher than that of the old group teaching between 10 to 20 years. Teachers who have long taught between 10 to 20 years have high professionalism from teachers who have been teaching for less than 10 years. Teachers who teach less than 10 years have a higher professionalism than teachers who have taught over 31 years. Based on the results of the above statistical analysis, that there is a difference of professionalism of teachers based on teaching duration among Madrasah Aliyah teachers. 


\section{E. The Influence of Khalifah Concept and Islamic Psychosocial on the Professionalism of Madrasah Aliyah Teachers}

Using a simple linear regression test is shown in table II that there is a value $(\mathrm{F}=140.700)$ and $\mathrm{Sig}=0.000(\mathrm{P}<0.05)$. This confirms that the concept of khalifah and psychosocial Islam has an influence on the professionalism of Madrasah Aliyah teachers in Riau Province. Based on statistical analysis, the hypothesis of research that states there is influence of the concept of khalifah and psychosocial Islam on the professionalism of Madrasah Aliyah teachers in Riau Province is accepted.

TABLE II. ANOVA

\begin{tabular}{|l|l|r|r|l|r|r|}
\hline \multicolumn{2}{|c|}{ Model } & $\begin{array}{c}\text { Sum of } \\
\text { Squares }\end{array}$ & Df & $\begin{array}{c}\text { Mean } \\
\text { Square }\end{array}$ & F & Sig. \\
\hline \multirow{4}{*}{1} & Regression & 88739,470 & 2 & 44369,735 & 140,70 &, $000^{\mathrm{b}}$ \\
& $\begin{array}{l}\text { Residual } \\
\text { Total }\end{array}$ & 99966,080 & 317 & 315,350 & 0 & \\
\hline
\end{tabular}

To see the magnitude of the influence of khalifah concept and psychosocial Islam on the professionalism of Madrasah Aliyah teachers, table III can illustrate that, where the value (R $=0.686 \mathrm{a})$ and the value $(\mathrm{R}$ Square $=0.470)$. This confirms that the influence of Islamic caliphate and psychosocial concept is 0.470 which if minimized then becomes $47 \%$ to the professionalism of Madrasah Aliyah Teachers. So this affirms that the concept of khalifah and psychosocial Islam contributes 47\% to the professionalism of Madrasah Aliyah teachers in Riau Province.

TABLE III. MODEL SUMMARY

\begin{tabular}{|c|c|c|c|c|}
\hline Model & $\mathbf{R}$ & $\begin{array}{c}\mathbf{R} \\
\text { Square }\end{array}$ & $\begin{array}{c}\text { Adjusted R } \\
\text { Square }\end{array}$ & $\begin{array}{c}\text { Std. Error of the } \\
\text { Estimate }\end{array}$ \\
\hline 1 &, $686^{\mathrm{a}}$ &, 470 &, 467 & 17,758 \\
\hline
\end{tabular}

The findings of this study indicate that the concept of caliphate-which consists of basic potential dimensions with the construct of sense, senses and heart; and the actual moral dimension with the construct of wisdom, syaja'ah (brave), 'iffah (simple), syakha' (generous), hilm (polite); jud (benevolence), and mahabbah (love) -which is owned by the teacher is able to deliver it as a professional teacher in his profession as an educator in educating the nation's children. The Madrasah Aliyah teacher as a khalifah can reflect the values of the Caliphate itself and become God's representative on earth to educate the nation's children into qualified of Islamic generation.

The professionalism of Madrasah Aliyah teachers is influenced greatly by the concept of the caliph itself in the process of learning. This is because he as the caliph reflects the divine attributes in his professional activities. So a caliph, who follows in the footsteps of Allah SWT according to man's ability in deeds in running makarim al-syari'a, has a wider range, that is concerning morality that is praiseworthy and avoid self-reproach. This can be observed from the acquisition of the power of the soul, such as by improving the power of mufakkara (thinking), but will result in the ability to distinguish between the rights and the false in the matter of faith, also can distinguish between the true and the lie in speech and can also distinguish between the jamil (beautiful) and qabih (ugly) in action. Similarly, by raising the power of shahwiya (lust) with 'iffa, then this power will be guided by judgment (generous) and generosity. Similarly, to improve the power hamiyya (angry surge), resulting in hilm (polite) which in turn can also produce syaja'ah (courageous). Similarly with these three powers, the soul will produce 'is (just) and ihsan (good-minded [30].

Based on this it is illustrated that the teacher as a khalifah are those who practice divine attributes or good morality in every behavior of his life on earth. So, human as a caliph will give birth to morality and then produce a good personality. Thus, human as khalifah will educate the man himself on earth that will produce moral behavior. Caliph as educator will educate human beings, not teaching and this is the difference of educators as khalifah and non-khalifah. Humans as khalifah will do educational activities (pedagogic) which will give birth to a morally human, while teaching activity is only instructional. Educating the ultimate goal is human morality with transformation of value, while teaching the ultimate goal is human cognitive with the transfer of knowledge. It is then that will bring themselves Madrasah Aliyah teacher became a professional teacher in carrying out his profession.

Teachers as a khalifah demands to be able to educate human morals on earth with the potential that is the basic foundation for him, namely the potential sense, senses, and heart. Educating human morals to be the main focus as a khalifah because educating it must be able to change human behavior from the less good with divine attributes. Of course also he as an educator must first have the morals in the behavior of his life.

Here illustrated that the teacher is the personification of the caliph as an educator created by Allah SWT on earth. The teacher as personification of the caliph depicts that the duties assumed by the caliphs desire the responsibilities and duties of the teacher in carrying out his profession. Allah Almighty created the Caliph on earth for a noble purpose that has benefits for the universe and everything that exists inside it. Thus, the task and function of the teacher and the things that surround it, in line with the duties and functions carried by humans as khalifah simultaneously. Thus, the concept of true professional teachers refers to the values contained in the concept of the caliph itself and this is also a crucial thing to have by today's teachers in order to be able to deliver learners on the purpose of life itself in accordance with the teachings of Islam.

The teacher as the personification of the caliph, illustrating as a human being a noble being, occupies a privileged position given by God to man on earth. Teacher-as human created by Allah SWT with his mind and his soul-according to Samsul Nizar [31], make it as Allah's creation creature that is very noble and has human beings. For it is not an exaggeration, if Allah SWT gives to man with his trust to become khalifah fi al-ardh, as well as a devotee to his creator who is guided by revelation (religious message). Master, as the Caliph on earth has an important and noble duty to educate human beings to be able to float all the potential possessed with the power of creativity to 
prosper nature as well as coloring the reality of the history of civilization with the mastery of science and technology.

When the teacher himself as the personification of the caliph, then he demanded the mastery of science as well as professional in the learning process to teach mankind on earth. Teachers who are able to bear students on the purpose of life in accordance with the principle of its creation [32]. Humans as khalifah fi al-ardh are creatures that God believes to be educators on earth. Therefore, man must preserve the trust given by escape from dependence other than to Allah SWT. Teachers should adorn themselves by imitating and training themselves in order to behave that lead to the characteristics of jamil (beautiful) possessed by Allah SWT, such as gracious, merciful, loving, protective, supervisor, giver, just, helpful, gentle, patient, wise, forgiving, avenger, and guidance [33].

Thus, the concept contained in the caliph must be a whole personality integrated in the teacher so that it can succeed as a representative of Allah SWT on earth and will become a professional teacher. Thus, a khalifah he must have the potential to be able to prosper the earth is integrated in learning. Man in the presence of Allah SWT, according to M. Hamdani Bakran Adz-Dzaky [34], is a remarkable creature by falling His choice to humans to become a khalifah as a substitute of Allah SWT in managing the divine nature and ecosystem of rahmatan li al'alamin. Therefore as a caliph, man is endowed by Allah with Divine potentials together with the presence of "nur" and "spirit" that is fitri in man, namely the potential of divine nur, the potential of the divine soul, the potential of the divine nafs, and the potential of the divine qalb, divine, and divine sensory potential.

The findings of this research are consistent with the research conducted by Kabuye Uthman Sulaiman [35], which states that humans as caliphs who have moral behavior are able to develop and improve human capabilities in the process of daily life in the move. Joko Kristanto [36] in the results of his research confirmed that the task of the caliph is to be a representative of God on earth, as a regulator (youngberry), keeper (hafiz), educate (murabbi). People who have the concept of the caliph can act wisely and wisely in managing the natural wealth and the earth so as to avoid the damage.

The results of this study also strengthen the research of Yesi Lisnawati, Aam Abdussalam, and Wahyu Wibisana [37] which states that someone who has khaliffa concept of enforcing the law of Allah SWT, be fair to all parties, have extensive knowledge and able to cooperate with others will have implications on the improvement of task -the teacher's duty to achieve the goal of Islamic education. Ade Nasrun [38] study of 165 Al-Azhar Islamic High School teachers confirms that one of the actual morals of the attitudes of trust is examined relating to 0.794 or $79.4 \%$ to success in the performance of teachers.

This study tends to see the caliph from leadership perspective. But in this study trying to explore the concept of Islam about the caliph that could be it can be applied in the world of Islamic education for teachers. In research Agus Ruswandi, with the approach of library research to produce human as khalifah has four tasks: 1). as the assignor, 2). as the recipient of the task, 3). Place or environment in which humans are located 4). The assignment materials they must carry out. The task of the Caliphate will not be successful if the assignment material is not carried out. The purpose of Islamic education is formulated based on the concept of human being as khalifah and servant of God. Because Islamic education in general aims to create people who are cautious and worship to Allah, this piety is the practice of human task as khalifah [39].

Likewise, the psychosocial dimension of Islam owned by madrasah teachers will lead them to become Islamic professional teachers. Therefore, the Islamic Psychosocial construct is very relevant in establishing the teacher self. The findings of this study confirm that the psychosocial Islam both directly and simultaneously with the concept of the khalifah influenced the professionalism of Madrasah Aliyah teachers. It is illustrated that the dimensions contained in Islamic psycho socialism can deliver Madrasah Aliyah teachers throughout Riau Province to have professionalism in the learning process. Thus the social development of a teacher as an attribute of his behavior contribute to the development of self become a professional in educating the children of Indonesia. In the context of psychology, the formation of identity is the main task in personality development that is expected to be achieved by the end of adolescence. If the development can be arranged properly, it will have a good effect on psychosocial strength [40].

This is consistent with Erikson's psychosocial theory of human development leading to the development of identity. Erikson asserted that human development applies continuously throughout his life [41]. Erikson [42] states in his psychosocial development theory that each individual through eight developmental rankings is named as psychosocial rank. Each ranking is illustrated by various psychological crises that the individual needs to solve before the individual will experience trouble to deal with the crisis in the future. Thus, a madrasah teacher who is in the development of adult level has its own problems. Therefore, a teacher's self-development is also experiencing a crucial stage. If the teacher is able to handle the crisis well, then he will successfully establish his identity and personality. If the teacher fails, it will be faced with the destruction and conflict of identity and will not be able to reach a professional teacher.

Teachers who have psychosocial Islam, then he will have a view that involves the perception, motivation, trust and social interaction that based on Islam to see a social problem that will affect the attributes of individual behavior in society. Based on this matter, the professional Madrasah Aliyah teacher is very need by his mastery of Islamic psychology based on Islamic teachings where behavior and identity in running profession professionally in madrasah based on view in seeing a social problem.

Based on the results of this study, researchers want to establish a model of professionalism development of Madrasah Aliyah teachers with the strengthening of the concept of khalifah and Islamic psychosocial is a discovery and model design resulting from this study. This research has found that the concept of khalifah is as a companion and antecedent to Islamic psychosocial to develop the professionalism of Madrasah Aliyah teachers. The position of the concept of 
khalifah as an Islamic psychosocial companion in this model means that the concept of khalifah is not merely an ordinary behavior, but the concept of khalifah is a behavior resulting from awareness beyond the shari'ah and is in the awareness of ihsan. The meaning, between the concept of khalifah and Islamic psychosocial is in the position of correlation relationship, which may be the practice of khalifah concept helps Islamic psychosocial or otherwise Islamic psychosocial helps the concept of khalifah. It is proved that the concept of khalifah in the model being fostered is able to develop the professionalism of Madrasah Aliyah teachers without going through Islamic psychosocial intermediaries.

This research has found that the concept of khalifah and Islamic psychosocial simultaneously can develop the professionalism of Madrasah Aliyah teachers in Riau Province, Indonesia. This connotation of the concept of khalifah and Islamic psychosocial as Islamic variables provides a justification that the concept of khalifah and Islamic psychosocial Islam as an instrument based on Islamic theory is very relevant to the context of professionalism improvement of madrasah teachers. This is because madrasah teachers are Islam, so the construct of khalifah concepts and Islamic psychosocial is very relevant owned by all Madrasah Aliyah teachers. The construct of the khalifah concept, in which the instrument is built on the basis of Islam by referring to the human position as the representative of Allah SWT on earth to educate mankind, can significantly deliver more professional madrasah teachers. Similarly, Islamic psychosocial constructs based on Islamic principles if owned by Madrasah Aliyah teachers will lead them to become professional Islamic teachers in educating future generations of quality.

\section{CONCLUSION AND RECOMMENDATION}

\section{A. Conclusion}

The results of this study confirm from gender, the concept of male caliphate is lower than women, and women's psychosocial Islam is higher than men. Meanwhile, the professionalism of male and female madrasah teachers is the same or not different. In terms of age, the concept of khalifah, and psychosocial Islam are the same or do not have differences. While the professionalism of Madrasah Aliyah teachers aged 41-50 years is higher than teachers aged $>51$ years, teachers $>$ 51 years older than those $<30$ years old, teachers $<30$ years of age are higher in professionalism than teachers aged $31-40$ years. In terms of certification, the concept of khalifah, psychosocial Islam and the professionalism of madrasah teachers who have been certified for more than 5 years are higher than teachers who are less than 5 (five) years old. Teachers who are less than 5 years certified are higher than teachers who have not been certified. In terms of teaching, the concept of caliph and psychosocial Islam of the old teacher taught 10-20 years older than 21-30 years and higher than $<10$ years and higher than the teacher who has been teaching $>30$ years. While the professionalism of older teachers teaches 2130 years is higher than $10-20$ and higher than $<10$ years and higher than teachers who have taught $>30$ years.

This study also concludes that the concept of caliphate directly affects the professionalism of Madrasah Aliyah teachers in Riau Province (0.772) or (77.2\%). Similarly, psychosocial Islam directly affects the professionalism of Madrasah Aliyah teachers in Riau Province for (0.468) or $(46.8 \%)$. While the concept of khalifah and Islamic psychosocial simultaneously can affect the professionalism of Madrasah Aliyah teachers in Riau Province (0.470) or (47\%).

\section{B. Recommendation}

The practical implications of this research may contribute to the Ministry of Religious Affairs of the Republic of Indonesia for the preparation of education curricula at the level of Islamic universities that provide teacher training by incorporating the concept material of khalifah and psychosocial Islam in order to form the professionalism of Madrasah Aliyah teachers throughout Indonesia. The very relevant concept of Islamic caliphate and psycho socialism is given to the students for their provision to be teachers in madrasahs in Indonesia and other general education. It is universally expected to strengthen the curriculum with an understanding of the concept of khalifah and Islamic psychosocial for Madrasah Aliyah teachers in Indonesia.

\section{REFERENCES}

[1] Mohammad Kosim, "Guru dalam Perspektif Islam", Jurnal Tadris, Vol. 3, No. 1, 2008, p. 45

[2] Syahraini Tambak, "Metode Bercerita dalam Pembelajaran Pendidikan Agama Islam", al-Thariqah: Jurnal Pendidikan Agama Islam, Vol. 1, No. 1, 2016, p. 1-26

[3] Tim Penyusun, Undang-Undang Republik Indonesia Nomor 20 Tahun 2003 tentang Sistem Pendidikan Nasional dan Undang-Undang Republik Indonesia Nomor 14 Tahun 2005 tentang Guru dan Dosen, Jakarta: Visi Media, 2008, p. 14

[4] Imam Nasruddin, Profesi dan Etika Guru, Jakarta: Kalam Mulia, 2013

[5] Ahmad Salim, "Meletakkan Kompetensi dan Profesionalisme Guru Pendidikan Agama Islam”, Jurnal Mukaddimah, Vol. 18, No. 1, 2012, p. 130-141

[6] Wartawan Kompas, "Mengapa Kompetensi Guru Tersertifikasi (Cenderng) Rendah?", Koran Kompas, Jakarta, 6 Agustus 2012, p. 8

[7] Hasil wawancara dengan beberapa kepala Madrasah Aliyah di Kota Pekanbaru, Kabupaten Kampar, Kabupaten Palalawan, Kabupaten Indragiri Hilir, Kabupaten Siak, Kabupaten Bengkalis, Kota Dumai dan Kabupaten Rokan Hulu, pada tanggal 12-14 April 2016

[8] Ismail Suardi Wekke \& Maimun Aqsha Lubis, "Educational Technology on Teaching and Learning of Integrated Islamic Education in Brunai Darussalam", Jurnal Ulumuna, Vol. 15, No. 1, 2015, p. 185-204

[9] Nevriyani, Pelayanan Bimbingan dan Konseling Berorientasi Khalifah fil Ardh, Bandung: Alfabeta, 2009, p. 78

[10] Khairil Anwar, "Pengaruh Mental-Kognitif islam dan Amalan Sunnah Melalui Pengantara Psikososial Islam dan Estim Kendiri terhadap Kawalan Diri dalam Kalangan Pesalah Laku Remaja", Disertasi Program Pascsarjana Universiti Kebangsaan Malaysia, Malaysia, 2014.

[11] Jenny Johnston, "Issues of Professionalism and Teachers: Critical Observations from Research and the Literature", Jurnal The Australian Association for Research in Education, Inc, vol. 13. No. 1, 2015, p. 299

[12] Nurlaila, "Profesionalisme Guru dalam Meningkatkan Mutu Pendidikan", Jurnal Pendidikan Islam Ta'dib, Vol. 18, No. 2, 2013, p. 260-269

[13] Muhammad Riza Zainuddin, "Manajemen Kepala Madrasah dalam Pengembangan Profesionalisme Guru Pendidikan Agama Islam", Jurnal Pendidikan Agama Islam Edukasi, Vol. 2, No. 2, 2014, p. 632-644

[14] Nyanyu Khodijah, "Reflective Learning sebagai Pendekatan Alternatif dalam Meningkatkan Kualitas Pembelajaran dan Profesionalisme Guru Pendidikan Agama Islam", Jurnal Studi Keislaman Islamica, Vol. 6, No.1, 2011, p. 180-189 
[15] Bambang Budi Wiyono, Kusmintardjo, \& Ahmad Supriyanto, Grand Design Model Pembinaan Profesional Guru Berbasis Determinan KinerjaGuru", Jurnal Ilmu Pendidikan, Vol. 20, No. 2, 2014, p. 163-175

[16] Subanji dan Isnandar, "Peningkatan Profesionalisme Guru melalui Teacher Quality Improvement Program (TEQIP) berbasis Lesson Study", Jurnal Teacher Quality Improvement Program, Vol. 1, No. 1, November 2010, h. 1-11

[17] Muhammaad Nasir, "Profesionlaimse Guru Pendidikan Agama Islam (Sebuah Upaya Peningkatan Mutu Mellaui LPTK)", Jurnal Dinamika Ilmu, Vol. 13, No. 2, 2013, p. 189-203. Ustazi, "Pendidik Profesional Perspektif al-Ghazali”, Jurnal Ilmiah Prodi Pendidikan Agama Islam alTa'dib, Vol. 5, No. 1, 2013, p. 9-24

[18] Raghib al-Isfahani, al-Dhari'a ila Makarim al-Syari'a, Abu Yazid al'Ajmy, (ed.), Kairo: Dar al-Wafa', 1987

[19] M. Hamdan Bakran Adz-Dzaky, Konseling dan Psikoterapi Islam, Yogyakarta: Fajar Pustaka Baru, 2004, p. 25

[20] Amril M, Etika Islam: Telaah Pemikiran Filsafat Moral Raghib alIsfahani, Yogyakarta: Pustaka Pelajar berkerja sama dengan LSFK2P, 2002, p. 77-85

[21] E. H. Erikson, Identity: Youth and Crisis, New York: W.W. Norton, 1968, p 234

[22] Khairil Anwar, "Pengaruh Mental-Kognitif Islam dan Amalan Sunnah Melalui Pengantara Psiko-sosial Islam dan Estim Kendiri terhadap Kawalan Diri dalam Kalangan Pesalah Laku Remaja”, Disertasi Doktor Falsafah Fakultas Sains Sosial dan Kemanusiaan, Malaysia: Uneversiti Kebangsaan Malaysia, 2014, p. 22

[23] Sutarmanto, "Kompetensi dan Profesionalisme Guru Pendidikan Anak Usia Dini”, Jurnal Visi Ilmu Pendidikan, Vol. 2, No. 2, 2014, p. 18

[24] Wahyudi, "Standar Kompetensi Profesional Guru", Jurnal Pendidikan Sosiologi dan Humaniora, Vol. 1, No. 2, 2010, p. 1

[25] Kementerian Agama Republik Indonesia, Peraturan Menteri Agama Nomor 16 Tahun 2010 Tentang Pengelolaan Pendidikan Agama pada Sekolah, Jakarta: Kementerian Agama Republik Indonesia, 2010, p. 14

[26] Sekretariat Negara Republik Indonesia, Peraturan Pemerintah Republik Indonesia No 74 Tahun 2008 tentang Guru, Jakarta: Sekretariat Negara RI, 2008, p. 13.

[27] Kementerian Agama Republik Indonesia, Peraturan Menteri Agama Nomor 16 Tahun 2010 Tentang Pengelolaan Pendidikan Agama pada Sekolah, Jakarta: Kementerian Agama Republik Indonesia, 2010, p. 14
[28] Anas Sudijono, Metode Penelitian Kombinasi, Bandung: Alfabeta, 2012, p. 45

[29] Sugiyono, Metode Penelitian Pendidikan (Pendekatan Kuantitatif, Kualitatif, dan R\&D), Bandung: Alfabeta, 2014, p. 123

[30] Amril M, Etika Islam: Telaah Pemikiran Filsafat Moral Raghib alIsfahani, Yogyakarta: Pustaka Pelajar berkerja sama dengan LSFK2P, 2002, p. 79

[31] Samsul Nizar, Hakikat Manusia dalam Perspektif Pendidikan Islam; Membangun Pola Pendidikan yang Humanistik, Pekanbaru: PPS UIN Suska Riau Press, 2009, p. 1

[32] Syahraini Tambak, Pendidikan Agama Islam: Konsep Metode Pembelajaran PAI, Yogyakarta: Graha Ilmu, 2014, p. 79

[33] Neviyarni S., Pelayanan Bimbingan dan Konseling Berorientasi Khalifah fil Ardh, Bandung: Alfabeta, 2009, p. 63

[34] M. Hamdan Bakran Adz-Dzaky, Konseling dan Psikoterapi Islam, Yogyakarta: Fajar Pustaka Baru, 2004, p. 25

[35] Kabuye Uthman Sulaiman, "Moral Responsibility of Man as Khlaifah: an Exposition of teh Foundations of a Just Order", International Journal of Business, Economics, and Law, Vol. 9, Issu 5, 2016, p. 190-198

[36] Joko Kristanto, "Konsep Khalifah dan Kesalehan Lingkungan dalam Tradisi Islam”, Jurnal Kebudayaan Islam Ibda', Vol. 10, No. 1, p. 114130

[37] Yesi Lisnawati, Aam Abdussalam, dan Wahyu Wibisana, "Konsep Khalifah dalam al-Qur'an dan Implikasinya terhadap Tujuan Pendidikan Islam", Jurnal Tarbiyah, Vol. 2, No. 1, 2015, p. 47-57

[38] Ade Nasrun "Hubungan antara Etod Kerja dan Sikap Amanah dengan Kinerja Guru pada SMA-SMA Islam Yayasan Pesantren al-Azhar", Tesis Program Pascasarjana Program Studi Timur Tengah dan Islam Kekhususan Kajian Islam dan Psikologi, Jakarta, Juli, 2011, p. 56

[39] Agus Ruswandi "Konsep Khalifah dalam Pendidikan Islam", Jurnal Pendidikan Islam dan Keilmuan, Vol. 7, No. 2, 2016, p. 1-15

[40] Tati Nurhayati, "Perkembangan Perilaku Psikososial pada Masa Pubertas", Edueksos: Jurnal Pendidikan Sosial dan Ekonomi, Vol. 4, No. 1, 2015, p. 1-15

[41] E. H. Arikson, Childhood and Society, New York: Norton, 1963, Second Edition, p. 135

[42] E. H. Erikson, Identity: Youth and Crisis, New York: W.W. Norton, 1968, p. 234 